\title{
Effect of Vanadate on Tissue Defense System in Rats with Streptozotocin-Induced Diabetes
}

\author{
Sivaprakasam MANEemegalaI, Natesan SEKAR, \\ and Saminathan GoviNDASAMY* \\ Department of Biochemistry, University of Madras, \\ Guindy Campus, Madras 600 025, India
}

(Received October 30, 1995)

\begin{abstract}
Summary The effect of sodium orthovanadate treatment on the activities of superoxide dismutase, catalase, glutathione peroxidase, glutathione S-transferase, and the level of lipid peroxide and glutathione of liver, kidney, heart, intestine and testes was studied in streptozotocininduced diabetic rats. Superoxide dismutase and catalase activities were lowered in liver, kidney, intestine, and testes of the diabetic rats, whereas catalase activity in heart and glutathione peroxidase activity in kidney were elevated. Glutathione peroxidase in liver, glutathione S-transferase in liver and intestine, and glutathione content in liver and testes were found to be decreased in the diabetic animals. The levels of lipid peroxide were found to be increased in all the tissues except the heart, where there was no change. Treatment of diabetic rats with sodium orthovanadate restored the altered activities of catalase, superoxide dismutase, glutathione peroxidase, glutathione S-transferase and the level of lipid peroxide and glutathione to their normal level. The present findings suggest that vanadate can effectively normalize the diabetesinduced alterations to tissue defense systems.
\end{abstract}

Key Words: diabetes, vanadate, tissue defense system

Alterations in tissue defense systems including chemical scavengers or antioxidant molecules and the enzymes catalase, superoxide dismutase, and glutathione peroxidase have been reported in streptozotocin diabetic rats [1]. The reactive oxygen radicals generated in diabetics are the causative factors for the complications such as ischemic heart disease [2], atherosclerosis [3], retinal damage [4], and renal complications [5]. The altered antioxidant systems seen during diabetes can be restored with insulin treatment $[1,6]$.

* To whom correspondence should be addressed. 
Vanadate has been shown to have insulin-like effects [7-10]: It has the ability to normalize impaired expression of genes involved in hepatic glucose metabolism of diabetic rats [7]; cardiac changes observed at the early stage of diabetes are prevented by vanadate [8]; diabetes-related alterations in phenylalanine hydroxylase expression can be nullified by oral administration of sodium orthovanadate [9]; Kimura et al. [10] observed that vanadate can normalize the cholic acid biosynthesis in diabetic rats. Furthermore, we have shown that treatment of diabetic rats with vanadate leads to normalization of urea cycle enzymes and lysosomal enzymes [11, 12]. Recently Srivastava et al. [13] have reported that the impaired antioxidant status in diabetes was improved by lithium therapy and that further vanadate supplementation potentiated the effectiveness of the lithium action. Vanadate, at a concentration of $0.6 \mathrm{mg} / \mathrm{ml}$, partially restored the altered endogenous defense mechanism in diabetic liver [14]. However, the exact effect of vanadate on the altered tissue defense system in diabetic rats is yet to be evaluated. Hence, in this present study, the effect of sodium orthovanadate on the altered tissue defense systems in streptozotocin diabetic rats was investigated.

\section{MATERIALS AND METHODS}

Male Wistar rats (Fredrick Institute of Plant Protection and Toxicology, Padappai, India) weighing 160-180 g were fasted for $24 \mathrm{~h}$ before induction of diabetes with streptozotocin (a gift from Dr. Jerry R. Colca, Upjohn Co., Kalamazoo, MI, U.S.A.). Rats were injected intraperitoneally with streptozotocin at a dose of $55 \mathrm{mg} / \mathrm{kg}$ body weight in $0.1 \mathrm{M}$ citrate buffer $(\mathrm{pH} \mathrm{4.5)}$. Control animals received citrate buffer alone. Streptozotocin-treated animals were allowed to drink $5 \%$ glucose solution for 2 days to overcome drug-induced hypoglycemia. Streptozotocin-treated and control animals were housed in individual well-ventilated cages and were fed a commercial rat diet (Lipton India Ltd., Calcutta, India) and given water ad libitum. The animals were considered diabetic when the fasting blood glucose concentration was above $240 \mathrm{mg} / \mathrm{dl}$.

After 1 month, the rats were divided into four groups, viz., normal, vanadatetreated control, diabetic, and vanadate-treated diabetic rats. The vanadate-treated rats drank water containing $0.5 \%$ sodium chloride and sodium orthovanadate (Aldrich Chemical Co., Inc., Milwaukee, WI, U.S.A.) at a dose of $0.9 \mathrm{mg} / \mathrm{day}$; it was freshly prepared every day. The normal and streptozotocin diabetic rats not treated with vanadate drank $0.5 \%$ sodium chloride in water. Sodium chloride was included in the drinking water because it is known to reduce vanadium-induced diarrhea [15]. After 15 days of vanadate treatment the rats were sacrificed by cervical decapitation and blood was collected. The blood was precipitated with $10 \%$ trichloroacetic acid, and the supernatant was used for the estimation of glucose [16]. Liver, kidney, heart, intestine, and testes were quickly dissected out and homogenized in chilled $0.1 \mathrm{M}$ Tris- $\mathrm{HCl}$ buffer in a Potter-Elvehjem Teflon homogenizer. The homogenate was used for the assay of superoxide dismutase (EC 
1.15.1.1) [17], catalase (EC 1.11.1.6) [18], glutathione peroxidase (EC 1.11.1.9) [19], glutathione S-transferase (EC 2.5.1.18) [20], lipid peroxidation [21], glutathione [22], and protein [23]. The data were statistically analyzed, and Student's $t$-test was used to compare the means of two groups.

\section{RESULTS}

The data in Table 1 show the blood glucose, body weight, fluid intake, and vanadate intake of the experimental rats. The blood glucose level was elevated significantly $(p<0.001)$ in diabetic rats and brought back to near the normal level in vanadate-treated diabetic rats. The body weight was decreased in diabetic animals when compared with that of normal ones. Diabetic rats had a volume of fluid intake increased significantly $(p<0.001)$ when compared with normal animals. The altered body weight and fluid intake in diabetic rats were normalized by the vanadate treatment. There was no significant difference in any parameter between vanadate-treated control and normal rats. The amount of vanadate intake was increased in vanadate-treated diabetic rats when compared with the amount taken in by the vanadate-treated control rats.

Activities of superoxide dismutase, catalase, glutathione peroxidase, and glutathione S-transferase in liver, kidney, heart, intestine and testes of experimental group of rats are shown in Table 2. Activities of superoxide dismutase and catalase were found to be decreased in liver, kidney, intestine, and testes of diabetic rats compared with their levels in normal rats. The enzyme glutathione peroxidase in the kidney and catalase in the heart of diabetic rats were increased in activity significantly $(p<0.001)$. Glutathione S-transferase in liver and intestine and glutathione peroxidase in liver were decreased in diabetic rats when compared with normal values. These altered enzyme levels in diabetic rats were normalized by vanadate treatment. Vanadate-treated control rats and normal ones showed no difference in these enzyme activities.

Table 3 depicts the levels of lipid peroxide and glutathione in the tissues of liver, kidney, heart, intestine, and testes of the experimental and control rats. The

Table 1. Blood glucose, body weight, amount of fluid intake, and vanadate intake in normal, vanadate-treated control, diabetic, and vanadate-treated diabetic rats.

\begin{tabular}{lcccc}
\hline & Normal & $\begin{array}{c}\text { Vanadate- } \\
\text { treated } \\
\text { control }\end{array}$ & Diabetic & $\begin{array}{c}\text { Vanadate- } \\
\text { treated } \\
\text { diabetic }\end{array}$ \\
\hline Glucose $(\mathrm{mg} / \mathrm{dl})$ & $85.6 \pm 6.2$ & $81.2 \pm 5.8$ & $256.2 \pm 18.5^{* * *}$ & $130.6 \pm 11.4^{* * *}$ \\
Body weight $(\mathrm{g})$ & $190 \pm 14$ & $192 \pm 10$ & $156 \pm 9^{* * *}$ & $173 \pm 11^{*}$ \\
Fluid intake $(\mathrm{ml} / \mathrm{kg} /$ day) & $225.3 \pm 21.6$ & $209.3 \pm 20.4$ & $534.2 \pm 51.7^{* * *}$ & $267.4 \pm 29.3^{* * *}$ \\
Vanadate intake $(\mathrm{mg} / \mathrm{kg} /$ day) & - & $62.7 \pm 6.1$ & - & $80.2 \pm 8.8$ \\
\hline
\end{tabular}

Values are expressed as mean \pm SEM for six animals in each group. ${ }^{*} p<0.05 ;{ }^{* * *} p<0.001$ : Diabetic vs. vanadate-treated diabetic or normal vs. diabetic.

Vol. 21, No. 2, 1996 
Table 2. Activities of catalase (CAT), superoxide dismutase (SOD), glutathione peroxidase (GSH-Px), and glutathione S-transferase (GST) in liver, kidney, heart, intestine, and testes of normal, vanadate-treated control, diabetic, and vanadate-treated diabetic rats.

\begin{tabular}{|c|c|c|c|c|}
\hline & Normal & $\begin{array}{l}\text { Vanadate- } \\
\text { treated } \\
\text { control }\end{array}$ & Diabetic & $\begin{array}{l}\text { Vanadate- } \\
\text { treated } \\
\text { diabetic }\end{array}$ \\
\hline \multicolumn{5}{|l|}{ Liver } \\
\hline CAT & $72.6 \pm 6.3$ & $73.2 \pm 6.9$ & $36.5 \pm 4.8^{* * *}$ & $54.5 \pm 5.8^{* * *}$ \\
\hline SOD & $6.53 \pm 0.82$ & $6.64 \pm 0.94$ & $3.23 \pm 0.75^{* * *}$ & $5.96 \pm 0.79 * * *$ \\
\hline GSH-Px & $80.6 \pm 6.4$ & $82.1 \pm 6.7$ & $54.7 \pm 5.2 * * *$ & $72.3 \pm 5.8^{* * *}$ \\
\hline GST & $10.4 \pm 1.2$ & $11.6 \pm 1.3$ & $7.4 \pm 0.82 * * *$ & $9.6 \pm 0.85^{* *}$ \\
\hline \multicolumn{5}{|l|}{ Kidney } \\
\hline $\mathrm{CAT}$ & $6.98 \pm 0.54$ & $7.12 \pm 0.59$ & $3.56 \pm 0.42^{* * *}$ & $5.84 \pm 0.51^{* * *}$ \\
\hline SOD & $3.02 \pm 0.31$ & $3.26 \pm 0.34$ & $1.52 \pm 0.20^{* * *}$ & $2.68 \pm 0.34^{* * *}$ \\
\hline GSH-Px & $42.3 \pm 4.5$ & $45.6 \pm 4.8$ & $58.6 \pm 5.8^{* * *}$ & $48.1 \pm 4.3^{* *}$ \\
\hline GST & $5.1 \pm 0.76$ & $4.8 \pm 0.62$ & $4.3 \pm 0.58$ & $4.5 \pm 0.61$ \\
\hline \multicolumn{5}{|l|}{ Heart } \\
\hline CAT & $0.22 \pm 0.033$ & $0.21 \pm 0.021$ & $1.29 \pm 0.14^{* * *}$ & $0.46 \pm 0.053^{* * *}$ \\
\hline SOD & $1.62 \pm 0.15$ & $1.53 \pm 0.14$ & $1.84 \pm 0.20$ & $1.66 \pm 0.17$ \\
\hline GSH-Px & $39.4 \pm 4.1$ & $38.6 \pm 4.0$ & $34.8 \pm 3.8$ & $36.5 \pm 3.6$ \\
\hline GST & $4.7 \pm 0.34$ & $4.6 \pm 0.36$ & $4.3 \pm 0.34$ & $4.2 \pm 0.39$ \\
\hline \multicolumn{5}{|l|}{ Intestine } \\
\hline CAT & $0.26 \pm 0.033$ & $0.28 \pm 0.041$ & $0.14 \pm 0.032 * * *$ & $0.22 \pm 0.022 * * *$ \\
\hline SOD & $3.41 \pm 0.32$ & $3.52 \pm 0.33$ & $1.82 \pm 0.28^{* * *}$ & $2.73 \pm 0.24^{* * *}$ \\
\hline GSH-Px & $34.6 \pm 3.8$ & $36.5 \pm 4.1$ & $31.5 \pm 3.9$ & $32.4 \pm 3.4$ \\
\hline GST & $8.5 \pm 0.94$ & $8.7 \pm 0.92$ & $5.4 \pm 0.63^{* * *}$ & $7.6 \pm 0.74 * * *$ \\
\hline \multicolumn{5}{|l|}{ Testes } \\
\hline CAT & $0.24 \pm 0.032$ & $0.26 \pm 0.031$ & $0.13 \pm 0.022^{* * *}$ & $0.21 \pm 0.024^{* * *}$ \\
\hline SOD & $1.84 \pm 0.17$ & $1.92 \pm 0.18$ & $1.26 \pm 0.14^{* * *}$ & $1.65 \pm 0.15^{* * *}$ \\
\hline GSH-Px & $30.9 \pm 3.4$ & $31.6 \pm 3.1$ & $28.5 \pm 2.9$ & $29.3 \pm 3.0$ \\
\hline GST & $9.4 \pm 0.86$ & $9.1 \pm 0.81$ & $9.8 \pm 0.93$ & $9.6 \pm 0.91$ \\
\hline
\end{tabular}

Values are expressed as mean \pm SEM for six animals in each group. The activities of the enzymes are expressed as follows: CAT, mol of hydrogen peroxide decomposed $/ \mathrm{min} / \mathrm{mg}$ protein; SOD, one unit of SOD activity is the amount of protein required to give $50 \%$ inhibition of epinephrine autoxidation; GSH-Px, nmol glutathione oxidized $/ \mathrm{min} / \mathrm{mg}$ protein; and GST $\mu \mathrm{mol}$ of 1-chloro-2,4-dinitrobenzene conjugate formed $/ \mathrm{min} / \mathrm{mg}$ protein. ${ }^{* *} p<0.01 ;{ }^{* * *} p<0.001$ : Diabetic vs. vanadate-treated diabetic or normal vs. diabetic.

lipid peroxide level in liver, kidney, intestine and testes of diabetic rats was significantly $(p<0.001)$ elevated over the level in normal rats. The glutathione level was found to be decreased in liver and testes of the diabetic rats. These altered levels in diabetic condition were brought back to near the normal level after administration of sodium orthovanadate. The levels of lipid peroxide and glutathione were the same for vanadate-treated control and normal rats.

\section{DISCUSSION}

The hypoglycemic and insulin-like action of vanadate was confirmed by its 
Table 3. Lipid peroxide (nmol malondialdehyde/mg protein) level and glutathione (nmol/g wet tissue) content in liver, kidney, heart, intestine, and testes of normal, vanadatetreated control, diabetic, and vanadate-treated diabetic rats.

\begin{tabular}{|c|c|c|c|c|}
\hline & Normal & $\begin{array}{c}\text { Vanadate- } \\
\text { treated } \\
\text { control }\end{array}$ & Diabetic & $\begin{array}{c}\text { Vanadate- } \\
\text { treated } \\
\text { diabetic }\end{array}$ \\
\hline \multicolumn{5}{|l|}{ Liver } \\
\hline Lipid peroxide & $1.42 \pm 0.13$ & $1.46 \pm 0.14$ & $2.16 \pm 0.24 * * *$ & $1.63 \pm 0.15^{* * *}$ \\
\hline Glutathione & $5.12 \pm 0.42$ & $5.06 \pm 0.41$ & $3.14 \pm 0.21^{* * *}$ & $4.26 \pm 0.36 * * *$ \\
\hline \multicolumn{5}{|l|}{ Kidney } \\
\hline Lipid peroxide & $0.76 \pm 0.082$ & $0.78 \pm 0.084$ & $1.18 \pm 0.126^{* * *}$ & $0.84 \pm 0.095^{* * *}$ \\
\hline Glutathione & $2.48 \pm 0.23$ & $2.64 \pm 0.24$ & $2.54 \pm 0.26$ & $2.53 \pm 0.22$ \\
\hline \multicolumn{5}{|l|}{ Heart } \\
\hline Lipid peroxide & $0.34 \pm 0.043$ & $0.36 \pm 0.045$ & $0.30 \pm 0.036$ & $0.32 \pm 0.031$ \\
\hline Glutathione & $1.56 \pm 0.16$ & $1.48 \pm 0.15$ & $1.52 \pm 0.15$ & $1.54 \pm 0.16$ \\
\hline \multicolumn{5}{|l|}{ Intestine } \\
\hline Lipid peroxide & $0.38 \pm 0.044$ & $0.39 \pm 0.046$ & $0.56 \pm 0.061 * * *$ & $0.41 \pm 0.050^{* * *}$ \\
\hline Glutathione & $4.16 \pm 0.48$ & $4.31 \pm 0.46$ & $4.56 \pm 0.48$ & $4.32 \pm 0.45$ \\
\hline \multicolumn{5}{|l|}{ Testes } \\
\hline Lipid peroxide & $0.65 \pm 0.058$ & $0.67 \pm 0.059$ & $0.86 \pm 0.076^{* * *}$ & $0.71 \pm 0.062^{* *}$ \\
\hline Glutathione & $1.34 \pm 0.12$ & $1.27 \pm 0.11$ & $0.71 \pm 0.058^{* * *}$ & $0.96 \pm 0.091^{* * *}$ \\
\hline
\end{tabular}

normalizing effect on the elevated blood glucose and polydipsia in diabetic rats. The anabolic effect of vanadate on body weight in diabetic rats [11] was also demonstrated in our present study. The increased amount of vanadate intake in the vanadate-treated diabetic rats versus the vanadate-treated control rats was due to the difference in the amount of fluid intake.

The enzymes superoxide dismutase, catalase, and glutathione peroxidase appear to be central to the defense of the cell against oxidative damage $[24,25]$. Increased catalase activity in the heart $[26,27]$ and glutathione peroxidase activity in the kidney [1] have been observed in diabetic rats. The increased catalase activity in heart may be due to the endogenous production of hydrogen peroxide. These increased enzyme activities may be their adaptive response to conditions of increased peroxidative stress with a corresponding increase in activity. [1]. Activities of superoxide dismutase and catalase are generally high in liver and kidney of normal rats [28]. Superoxide dismutase and catalase activities were earlier found to be decreased in liver, kidney, intestine, and testes tissues [27, 29, 30]; and glutathione peroxidase activity was low in the liver of diabetic rats [1]. The decreased activities of these enzymes, which we also observed in this present study in diabetes may be due to the increased generation of reactive oxygen radicals such as superoxide and hydrogen peroxide, which leads to the inactivation of these enzyme activities [1]. Decreased intestinal superoxide dismutase may contribute to ischemic bowel disease in diabetes [29].

Vol. 21, No. 2, 1996 
The enzyme glutathione S-transferase is a member of a complex supergeneencoded family of detoxification enzymes found in wide variety of animal tissues [31]. The activity of glutathione S-transferase was decreased in diabetic rat liver [32], which finding we confirmed presently. The decreased level in the diabetic condition may be due to the down regulation of glutathione S-transferase subunits [32]. The altered levels of antioxidant enzyme systems in diabetic rats were normalized by insulin treatment [27]. Vanadate treatment of the diabetic rats restored the altered enzyme activities to near their normal level, and this may be due to its protective action on tissues against reactive oxygen radicals or to its suppression of the production of free radicals.

The initiation of lipid peroxidation is carried out by free radicals such as superoxide, hydroxyl radical, and hydrogen peroxide, all of which cause cellular injury [33]. We observed increased lipid peroxidation in liver, kidney, intestine, and testes of the diabetic rats. Such increase was found earlier in testes of rats with experimental obesity [34]. The increased lipid peroxidation in these tissues suggests the presence of oxidative cellular injury [26], and this may be due to the decrease in the activity of antioxidant enzymes in diabetic rat tissues. The unaltered lipid peroxidation in heart may be due to increased resistance to oxidative damage. Glutathione content was found to be decreased in the diabetic liver and testes. Decreased glutathione in diabetes might be due to increased degradation or decreased synthesis of glutathione [6]. Decreased rate of incorporation of glycine into glutathione in liver and diaphragm of diabetic animals suggested a decreased rate of glutathione synthesis in diabetes [35]. The alterations observed in the level of lipid peroxide and glutathione content in our diabetic rats were normalized by vanadate treatment, as observed earlier with insulin treatment [6].

Saxena et al. [14] reported that vanadate $(0.6 \mathrm{mg} / \mathrm{ml})$, an insulin-mimetic agent, could not completely restore the altered endogenous defense systems in diabetic rats. The partial response of vanadate may have been due to its higher concentration used, as 0.6 and $0.8 \mathrm{mg} / \mathrm{ml}$ vanadate in diabetes was found to be toxic [36, 37]. The fact that altered levels of lipid peroxide and glutathione were brought back to near their normal level by vanadate $(0.9 \mathrm{mg} /$ day $)$ in our study proves the mitigating action of vanadate, like insulin, on the diabetic condition. In conclusion, altered tissue defense systems in diabetic rats indicated the degenerative status in diabetes and normalization of vanadate treatment confirmed its insulin-like action. Further, it is worthwhile to mention the non-toxic nature of sodium orthovanadate treatment in the control rats.

Authors S.M. and N.S. thank the Council of Scientific and Industrial Research for the financial assistance in the form of a Senior Research Fellowship and Research Associateship, respectively.

\section{REFERENCES}

1. Wohaieb, S.A., and Godin, D.V. (1987): Alterations in free radical tissue-defense mecha- 
nisms in streptozotocin-induced diabetes in rats. Effect of insulin treatment. Diabetes, 36, 1014-1018.

2. Kessler, I.I. (1971): Mortality experience of diabetic patients. Am. J. Med., 51, 715-724.

3. Kannell, J.W., and McGee, D.L. (1979): Diabetes and cardiovascular risk factors; The Framingham study. Circulation, 59, 8-13.

4. Crouch, R., Kimsey, G., Priest, D.G., Sarda, A., and Buse, M.G. (1978): Effect of streptozotocin on erythrocyte and retinal superoxide dismutase. Diabetologia, 15, 53-57.

5. Paller, M.S., Hoidal, J.R., and Ferris, T.F. (1984): Oxygen free radicals in ischemic acute renal failure in the rat. J. Clin. Invest., 74, 1156-1164.

6. Loven, D., Schedl, H., Wilson, H., Daabees, T.T., Stegink, L.D., Diekus, M., and Oberley, L. (1986): Effect of insulin and oral glutathione on glutathione levels and superoxide dismutase activities in organs of rats with streptozotocin induced diabetes. Diabetes, $\mathbf{3 5}$, 503-507.

7. Brichard, S.M., Desbuquois, B., and Girard, J. (1993): Vanadate treatment of diabetic rats reverses the impaired expression of genes involved in hepatic glucose metabolism: Effects on glycolytic and gluconeogenic enzymes, and on glucose transporter GLUT 2. Mol. Cell. Endocrinol., 91, 91-97.

8. Ozcelikay, A.T., Yidizoglu-Ari, N., Ozuari, A., Ozturk, Y., and Altan, V.M. (1993): The effect of vanadate on alloxan diabetic rat atria. Diabetes Res. Clin. Pract., 19, 189-194.

9. Green, A.K., McDowall, I.L., Richardson, S.C., and Fisher, M.J. (1992): The effect of vanadate upon the expression of phenylalanine hydroxylase in streptozotocin diabetic rat liver. Biochim. Biophys. Acta, 1180, 21-27.

10. Kimura, K., Ogura, Y., and Ogura, M. (1992): Biosynthesis of cholic acid accelerated by diabetes: Its mechanism and effect of vanadate administration. Biochim. Biophys. Acta, 1123, 303-308.

11. Maneemegalai, S., Sekar, N., and Govindasamy, S. (1994): Insulin-like effect of sodium orthovanadate on urea-cycle enzymes in streptozotocin diabetic rats. J. Clin. Biochem. Nutr., 16, $187-192$.

12. Maneemegalai, S., Sekar, N., and Govindasamy, S. (1994): Regulatory role of Sodium orthovanadate on the activities of lysosomal enzymes in streptozotocin diabetic rats. $\mathrm{Med}$. Sci. Res., 22, 757-759.

13. Srivastava, P., Saxena, A.K., Kale, R.K., and Baquer, N.Z. (1993): Insulin like effects of lithium and vanadate on the altered antioxidant status of diabetic rats. Res. Commun. Chem. Pathol. Pharmacol., 80, 283-293.

14. Saxena, A.K., Srivastava, P., Kale, R.K., and Baquer, N.Z. (1993): Impaired antioxidant status in diabetic rat liver. Effect of vanadate. Biochem. Pharmacol, 45, 539-542.

15. Heyliger, C.E., Tahliani, A.G., and McNeill, J.H. (1985): Effect of vanadate on elevated blood glucose and depressed cardiac performance of diabetic rats. Science, 227, 1474-1476.

16. Sasaki, T., and Matsui, S. (1972): Effect of acetic acid concentration on the colour reaction in the O-toluidine-boric acid method for blood glucose determination. Rinsho Kagaku, 1, 346-353.

17. Misra, H.P., and Fridovich, I. (1972): The role of superoxide anion in the autoxidation of epinephrine and a simple assay for superoxide dismutase. J. Biol. Chem., 247, 3170-3175.

18. Takahara, S., Hamilton, B.H., Nell, J.V., Kobara, T.Y., Ogura, Y., and Nishimura, E.T. (1960): Hypocatalasemia: A new genetic carrier state. J. Clin. Invest., 29, 610-619.

19. Necheles, T.F., Boles, T.A., and Allen, D.M. (1968): Erythrocyte glutathione peroxidase deficiency and hemolytic disease of the newborn infant. J. Pediatr., 72, 319-324.

20. Habig, W.H., Pabst, M.J., and Jakoby, W.B. (1974): Glutathione S-transferases: The first enzymatic step in mercapturic acid formation. J. Biol. Chem., 249, 7130-7139.

21. Ohkawa, H., Ohishi, N., and Yagi, K. (1979): Assay for lipid peroxides in animal tissue by thiobarbituric acid reaction. Anal. Biochem., 95, 351-358.

22. Moron, M.S., Depierre, J.W., and Mannervik, B. (1979): Levels of glutathione, glutathione 
reductase and glutathione S-transferase activities in rat lung and liver. Biochim. Biophys. Acta, 582, 67-78.

23. Lowry, O.H., Rosebrough, N.J., Farr, A.L., and Randall, R.J. (1951): Protein measurement with the Folin-phenol reagent. J. Biol. Chem., 193, 265-275.

24. Lammi-keefe, C.J., Swan, P.B., and Hegarty, P.V.J. (1984): Evidence for increased peroxidative activity in muscles from streptozotocin diabetic rats. Proc. Soc. Exp. Biol. Med., 176, 27-31.

25. Poonam, Y., Sarkar, S., and Bhatnagar, D. (1994): Protective effect of glutathione and selenium against alloxan induced lipid peroxidation and loss of antioxidant enzymes in erythrocytes. J. Biosci., 19, 19-25.

26. Asayama, K., Hayashibe, H., Dobashi, K., Niitsu, T., Miyao, A., and Kato, K. (1989): Antioxidant enzyme status and lipid peroxidation in various tissues of diabetic and starved rats. Diabetes Res., 12, 85-91.

27. Godin, D.V., Wohaieb, S.A., Garnett, M.E., and Goumeniouk, A.D. (1988): Antioxidant enzyme alterations in experimental and clinical diabetes. Mol. Cell. Biochem., 84, 223-231.

28. Wohaieb, S.A., and Godin, D.V. (1987): Starvation related alterations in free radical tissue defense mechanisms in rats. Diabetes, 36, 169-173.

29. Loven, D.P., Schedl, H.P., Oberley, L.W., Wilson, H.D., Bruch, L., and Niehaus, C.L. (1982): Superoxide dismutase activity in the intestine of the streptozotocin diabetic rats. Endocrinology, 111, 737-742.

30. Matkovics, B. (1977): Effect of plant and animal tissue lesions on superoxide dismutase activities, in Superoxide and Superoxide Dismutases, ed. by Michelson, A.M., McCord, J.M., and Fridorich, I., Academic Press, New York, pp. 501-515.

31. Hayes, P.C., Harrison, D.J., Bouchier, I.A.D., McLellan, L.I., and Hayes, J.D. (1989): Cytosolic and microsomal glutathione S-transferase isoenzymes in normal human liver and intestinal epithelium. Gut, 30, 854-859.

32. Murray, M., and Zaluzny, L. (1989): Comparative effects of genetic obesity and streptozotocin-diabetes on rat liver cytosolic glutathione S-transferase activities. Nutr. Res., 9, $1151-1160$.

33. Ashwood-Smith, M.J. (1975): Current concepts concerning radioprotective and cytoprotective properties of dimethyl sulfoxide in cellular system. Ann. N.Y. Acad. Sci., 243, 246-256.

34. Lomsadze, T.E., and Tsartisidze, M.A. (1990): Lipid peroxidation in plasma membrane of the rat testis in experimental obesity. Soobshch. Akad. Nauk. Gruz. SSR, 138, 153-156.

35. Krahl, M.E. (1953): Incorporation of $\mathrm{C}^{14}$ aminoacids into glutathione and protein fractions of normal and diabetic rat tissues. J. Biol. Chem., 200, 99-109.

36. Sekar, N., William, S., Balasubramaniyam, N., Kamarajan, P., and Govindasamy, S. (1990): Optimization of sodium orthovanadate to treat streptozotocin-induced diabetic rats. $J$. Biosci., 15, 67-75.

37. Meyerovitch, J., Farfel, Z., Sack, J., and Shechter, Y. (1987): Oral administration of vanadate normalizes blood glucose levels in streptozotocin-treated rats. Characterization and mode of action. J. Biol. Chem., 262, 6658-6662. 